\title{
A DIRECTIONAL CHANGE IN THE GENETIC CON- STITUTION OF A NATURAL POPULATION OF DROSOPHILA PSEUDOOBSCURA
}

\author{
BY THEODOSIUS DOBZHANSKY \\ Department of Zoology. Columbia University, New York
}

\section{INTRODUCTION}

Received 29.xi.46

Natural populations of Drosophila pseudoobscura and of the related species, $D$. persimilis (formerly known as race $B$ ) and $D$. miranda, show a remarkable variability in the gene arrangement in their chromosomes. The variations are due to inversion of chromosome segments ; the third chromosome is for unknown reasons much more variable than the rest. Two, or as many as seven, gene arrangements of this chromosome occur in the populations of $D$. pseudoobscura in most, though not in all, localities in which the species is found. More than half of the wild individuals are inversion heterozygotes. The distribution in space of the gene arrangements is by no means uniform. A given arrangement may occur commonly in some geographic regions but rarely in others. No one arrangement is found throughout the distribution area of the species; hence, there is no " normal" or " wild-type" arrangement.

The relative frequencies of a given gene arrangement often vary regularly from region to region and thus produce geographic gradients or clines (Dobzhansky and Sturtevant, 1938; Dobzhansky and Epling, 1944). Moreover, the frequencies have been found to vary not only in space but in time. Population samples taken at intervals of several months in the same locality often show significant differences in composition. A special study of temporal variations was undertaken at three localities on Mount San Jacinto, California. These localities, Keen Camp, Piñon Flats and Andreas Canyon, are Io to I 5 miles apart, but lie at different elevations and represent three very different ecological situations. Population samples were collected at approximately monthly intervals during the breeding seasons in four consecutive years, I939-1942.

As previously reported (Dobzhansky, I943), the gene arrangements not only differ in frequencies at each locality, but the monthly change in frequency of at least two arrangements was found to be cyclic and associated with the seasonal cycle at Piñon Flats and Andreas Canyon. It was postulated that these cyclic changes are the result of natural selection whereby the arrangements better adapted to the conditions which prevail during a given season increase in frequency 
as the season advances. This hypothesis, which was derived from observations of wild populations, has since been confirmed by experiments of artificial models of populations bred in specially constructed cages (Wright and Dobzhansky, 1946). It was found that inversion homozygotes and heterozygotes may differ strikingly in adaptive value, and that heterozygotes are favoured over both homozygotes. Therefore, the artificial populations undergo changes which result in reaching an equilibrium at which all the gene arrangements are preserved to some extent. It was also found that the adaptive value of a given gene arrangement may differ with different temperatures: the changes observed were at temperatures around $25^{\circ} \mathrm{C}$., but none were found at $16.5^{\circ} \mathrm{C}$.

The cyclic changes referred to above were found at Piñon Flats and at Andreas Canyon and have remained relatively constant from year to year between 1939 and 1946 . In other words, there has been no significant change in trend. At Keen Camp the situation is different. During the same period the population there has remained relatively constant in composition from season to season, but the frequencies of gene arrangements have changed from year to year and are now quite appreciably different from what they were in 1.939. In other words, instead of a seasonal cyclic change there is a directional trend. The causes of this phenomenon are still obscure, but the fact that changes of this sort may occur in natural populations is of great interest. The relevant data are reported in this paper.

This investigation has been supported in part by a grant from the Carnegie Institution of Washington. However, it was made possible only thanks to the friendly co-operation of Professor Carl Epling and Mr Alexander Sokoloff, who have collected population samples in 1945 and 1946 as well as some of those in 1939-1942. The assistance of Miss Irene Markreich, Mr Bruce Wallace and Mr Boris Spassky in culturing the flies and in the preparation of slides of the salivary glands is gratefully acknowledged.

\section{MATERIAL AND TECHNIQUE}

The San Jacinto Range is one of several separating the Colorado desert from the coastal plain of Southern California. Keen Camp lies at an elevation of approximately 4400 feet on the northwestern shoulder of the mountain, in the ponderosa pine belt. The locality at Piñon Flats is only about 500 feet lower than Keen Camp, but lies on the desert slope and supports a very different vegetation dominated by the piñon pine. The elevation of Andreas Canyon is 800 feet ; it is located on the desert's edge at the foot of the mountains. The most conspicuous member of its vegetation is the palm, Washingtonia filifera. More information regarding the environment of these localities may be found in the paper of Wright, Dobzhansky and Hovanitz (1942).

The collections of I 939 were made at five stations at Keen Camp and at two stations each at Piñon Flats and Andreas Canyon. A 
"station" is at most an area Ioo yards in diameter. The distances between stations within a locality are from 200 yards (Andreas) to $2 \frac{1}{2}$ miles (Keen Camp). The localities are at most 15 miles apart. In I94I and I942 population samples were taken mainly at only one station in each locality. In 1945 and 1946 the collections were made at the stations Piñon $A$ and Keen $A$ or Keen D (see Wright, Dobzhansky and Hovanitz, I942). The data for 1939-1942 have been published (Dobzhansky, I943). As shown in that paper, the relative frequencies of the gene arrangements in the populations of different stations within a locality are usually similar. Furthermore, a study of the dispersion rates of the flies (Dobzhansky and Wright, I943) has shown that interchange of individuals between populations within the area of a locality is so rapid that no permanent genetic differences between the stations are likely to be established or maintained. It is, therefore, legitimate to treat the localities as units so far as the frequencies of the gene arrangements are concerned.

Females collected in nature were placed singly in culture bottles and allowed to produce offspring. Hence, examination of any larva from the offspring of a female permits the determination of the gene arrangements in two homologous wild chromosomes. Wild males were also crossed in individual cultures to females from a homozygous stock of known chromosomal structure. In this case examination of seven larvæ from each culture permits determination of the gene arrangement in two homologous chromosomes of the father, subject to one chance in sixty-four of mistaking a structural heterozygote for a homozygote.

\section{SEASONAL CYCLES AND THE ABSENCE OF A YEAR-TO-YEAR TREND AT PIÑON FLATS}

The data for the Piñon Flats population are summarised in table I. Five gene arrangements in the third chromosome were found in this

TABLE I

Percentage frequencies of the gene arrangements in different samples at PIÑNON FLATS: $S T=$ Standard $; A R=$ Arrowhead $; C H=$ Chiricahua $; T L=$ Tree Line

\begin{tabular}{|c|c|c|c|c|c|c|c|c|c|c|c|c|}
\hline $\begin{array}{c}\text { Month and } \\
\text { Year }\end{array}$ & ST & AR & $\mathrm{CH}$ & $\mathrm{TL}$ & $n$ & Month and & Year & ST & AR & $\mathrm{CH}$ & TL & $n$ \\
\hline April I 939 & $.50 \cdot 8$ & 29.5 & I $3 \cdot 1$ & $6 \cdot 6$ & $6 I$ & April I 94 I & - & $\cdot 5^{8 \cdot 2}$ & $20 \cdot 0$ & $17 \cdot 3$ & $4 \cdot 5$ & $I I O$ \\
\hline May I 939 & . $27 \cdot 9$ & 35.8 & $30 \cdot 0$ & $6 \cdot 3$ & 240 & May I 94 I & . & . $44 \cdot 0$ & $28 \cdot 0$ & 24.0 & 4.0 & 100 \\
\hline June I 939 & . 29.9 & $35 \cdot 1$ & $30 \cdot 5$ & $4 \cdot 5$ & 154 & June I 94I & . & $\cdot 3^{2 \cdot 9}$ & $32 \cdot 3$ & $32 \cdot 3$ & $2 \cdot 6$ & 192 \\
\hline Aug. I 939 & . 35.9 & $33 \cdot 3$ & $25 \cdot 6$ & $5 \cdot I$ & 156 & Aug. I 94 I & . & . $5 \times \cdot 9$ & $2 I \cdot 3$ & 25.9 & 0.9 & 108 \\
\hline Sept. I 939 & . $5^{1 \cdot 1}$ & $22 \cdot 6$ & $23 \cdot 2$ & $3 \cdot 2$ & 190 & Sept.-Oct. & I 94 I & . $56 \cdot 2$ & I $8 \cdot 8$ & $16 \cdot 3$ & $8 \cdot 7$ & 80 \\
\hline Oct. I 939 & . $54 \cdot 6$ & $25 \cdot 4$ & $16 \cdot 6$ & $3 \cdot 5$ & 284 & Nov.-Dec. & 1941 & .450 & $24 \cdot 0$ & 240 & $7 \cdot 0$ & 100 \\
\hline Mar. I $94^{\circ}$ & . $44 \cdot 6$ & $20 \cdot 2$ & $30 \cdot 1$ & $5 \cdot 2$ & 386 & April I $94^{2}$ & $\cdot$ & . $51 \cdot 0$ & $21 \cdot 6$ & I $9 \cdot 6$ & $7 \cdot 8$ & 102 \\
\hline Apr. I $94^{\circ}$ & . 34.7 & $28 \cdot 4$ & $33 \cdot 5$ & $3 \cdot 4$ & 176 & May I $94^{2}$ & - & . $4^{8} \cdot 0$ & I 7.0 & $25^{\circ} \mathrm{O}$ & $10 \cdot 0$ & 100 \\
\hline May I $94^{\circ}$ & . $28 \cdot 2$ & $27 \cdot 2$ & $39 \cdot 6$ & $5 \cdot 0$ & 202 & June I $94^{2}$ & . & . $29 \cdot 8$ & $22 \cdot 8$ & 40.4 & $7 \cdot 0$ & 114 \\
\hline June I $94^{\circ}$ & . $24 . \mathrm{I}$ & $30 \cdot 0$ & $41 \cdot 8$ & $4 \cdot I$ & 170 & July I $94^{2}$ & - & . $4 r \cdot 9$ & $2 \mathrm{I} \cdot 8$ & $30 \cdot 6$ & $5 \cdot 6$ & 124 \\
\hline Sept. I 940 & . $34 \cdot 6$ & $25^{\circ} 0$ & $37 \cdot 5$ & $2 \cdot 9$ & 104 & April I 945 & . & - $32 \cdot 7$ & $3 \mathrm{I} \cdot 3$ & $34 \cdot I$ & $2 \cdot 0$ & 352 \\
\hline Nov. I 940 & - 375 & $3^{2 \cdot 5}$ & $26 \cdot 3$ & $3 \cdot 7$ & 80 & Mar. I 946 & - & $56 \cdot 5$ & $18 \cdot 3$ & $18 \cdot 3$ & $7^{\circ} \cdot 0$ & $55^{8}$ \\
\hline Mar. I94I & . $56 \cdot 4$ & 10.9 & $23 \cdot 6$ & $9 \cdot I$ & IIO & June I 946 & . & $26 \cdot 2$ & $23 \cdot \overline{8}$ & $43 \cdot 8$ & $6 \cdot 2$ & 500 \\
\hline
\end{tabular}


population : Standard (henceforth abbreviated ST), Arrowhead (AR), Chiricahua (CH), Tree Line (TL) and Santa Cruz. The last-named is very rare, amounting to only 0.5 per cent. of the total ; in table $\mathrm{x}$ the Santa Cruz chromosomes are grouped with the TL chromosomes. For descriptions of the diagnostic features of these gene arrangements and other relevant data see Dobzhansky and Epling (1944).

Among the 4853 chromosomes studied from Piñon Flats, $40 \cdot 70$ per cent. were ST, $25^{\circ} 44$ per cent. AR, $29 \cdot 05$ per cent. $\mathrm{CH}$ and 5. I I per cent. TL (and Santa Cruz). Examination of table I shows that the frequencies of the gene arrangements vary from month to month, and furthermore that the variation is regular and cyclic. In each of the years 1939, r 940, I 94 I, I 942 and 1946 the minimal frequency of ST chromosomes was reached in the month of June and the maximal either in late autumn or in early spring. The maximal frequencies of $\mathrm{CH}$ chromosomes, on the contrary, or urred invariably in June, while the minima fell either on late autumn or on early spring. The variations of AR and TL are irregular.

The statistical significance of the seasonal variations is beyond question. Chi-squares have been computed for the differences between months within each of the years 1939, 1940, 194I and 1942; all these chi-squares have probabilities of 0.0 I or less of occurrence by chance (in these calculations three classes of chromosomes were distinguished, namely ST, CH and others). The difference between the samples taken in March and in June of 1946 is likewise highly significant. Summing up the data by months of collecting, one obtains the following figures that describe the seasonal trends in the frequencies of the gene arrangements (table 2). The frequency of

TABLE 2

Seasonal variation of the frequencies of the gene arrangements at PIÑON FLATS (in per cent.). Averages of 1939-1946

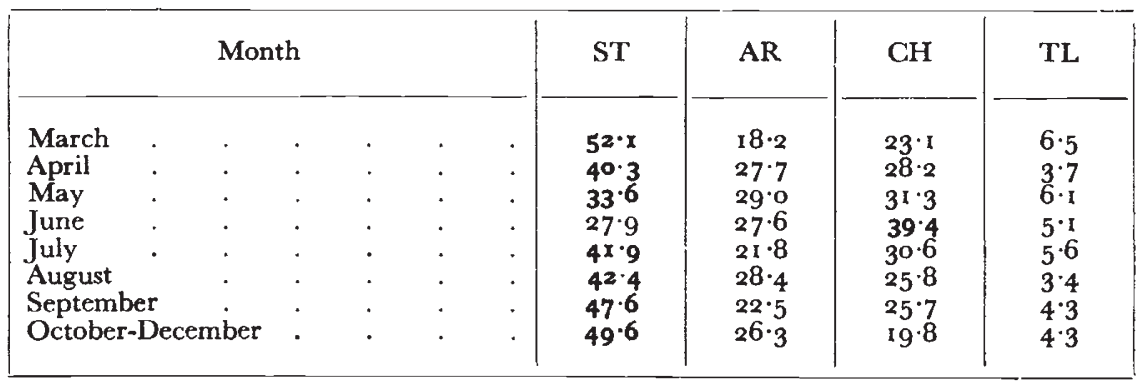

ST falls, and that of $\mathrm{CH}$ rises, during spring; a reverse change occurs during summer; no appreciable alterations take place during autumn and winter.

A possibility now to be examined is that, superimposed on the cyclic seasonal variations, there may exist a more sustained trend of change in frequencies. One attempt to approach this problem was 
made by comparing the frequencies in the totals for the different years of collecting, and very significant differences between these frequencies were found (Dobzhansky, 1943). But a drawback to this method is that samples taken in the same months of different years were not equal in size. Since seasonal changes in the frequencies of the gene arrangements are known to occur, the differences between the yearly totals may accordingly be spurious at least in part. A better method would be to compare the frequencies observed during the same months in different years. The period of collecting at Piñon Flats

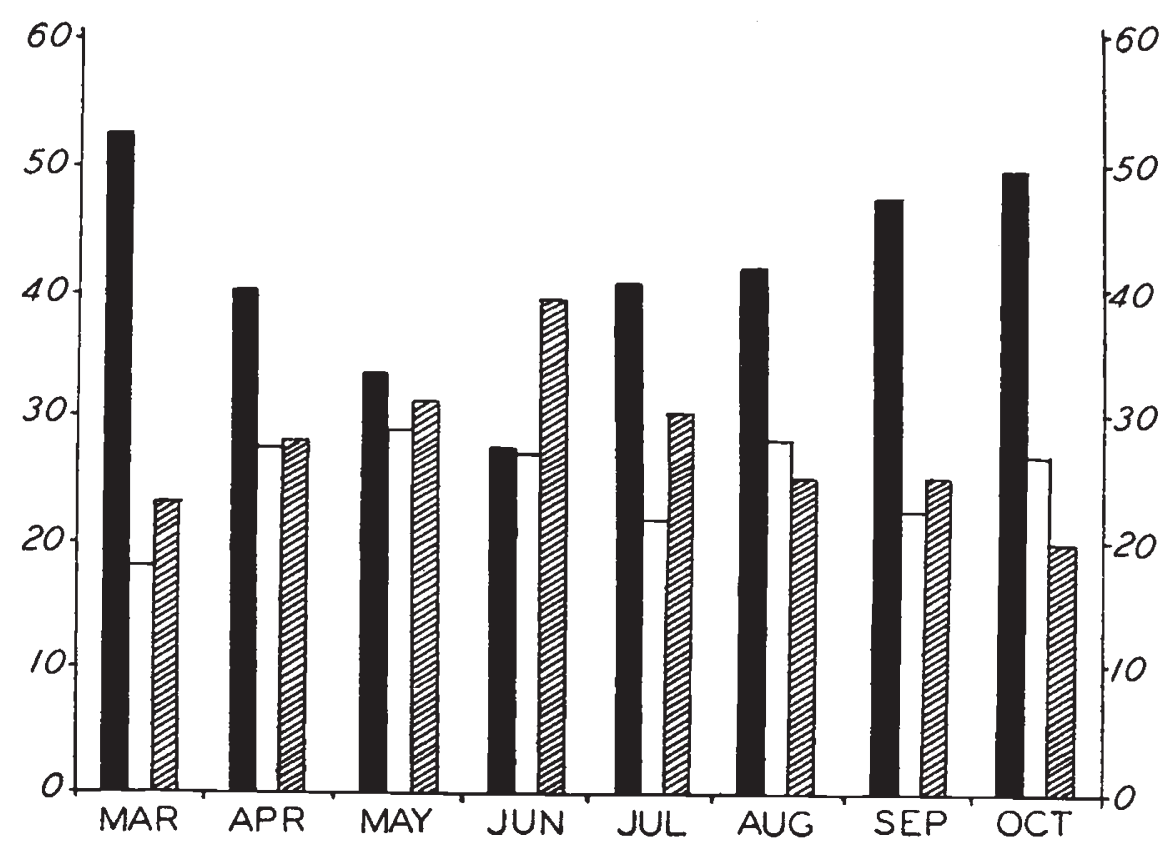

Fig. 1.-Relative frequencies of chromosomes with different gene arrangements on different months in the population of PINON FLATS. Ordinates-frequencies in per cent.; Black columns-ST chromosomes; white columns-AR chromosomes; and hatched columns- $\mathrm{CH}$ chromosomes. Combined data for all the years when collecting has been made.

was from March to December (table I). Comparison of samples obtained in March, April, June, August, September and OctoberDecember of different years was therefore made (only one sample was obtained in July of 1942). These comparisons disclose what are undoubtedly significant differences for March, April, May, August and September (chi-squares corresponding to probabilities of 0.01 or less). The samples collected in June are not significantly different (chi-square 15.75 , which for 8 degrees of freedom has a probability of about 0.05 ), and the same is true for the October-December samples (probability about $0 \cdot 06$ ).

Thus data show that the composition of the Piñon Flats population at comparable seasons of successive years, although not identical, 
nevertheless has no consistent trend. The year I 940 to be sure, showed higher frequencies of $\mathrm{CH}$ and lower ones of ST than observed either in 1939 or in $1941-1946$. But the situation was reversed in I94I, when the frequencies of ST tended to be higher and of $\mathrm{CH}$ lower than in other years, although this difference is less marked than the one observed in 1940. Apart from I940 the samples taken in corresponding months of different years prove to be fairly similar in composition. The chi-squares and their probabilities for the frequencies of ST on different years are as follows :-

\begin{tabular}{|c|c|c|c|}
\hline Months & $\chi^{2}$ & $\begin{array}{l}\text { Degrees of } \\
\text { freedom }\end{array}$ & $\mathrm{P}$ \\
\hline March & $2 \cdot 39$ & 2 & 0.3 \\
\hline April & 3.43 & 4 & 0.5 \\
\hline May & $20 \cdot 97$ & 6 & 0.002 \\
\hline June & $14.3^{1}$ & 6 & 0.03 \\
\hline August & $9 \cdot 3^{8}$ & 2 & 0.01 \\
\hline September. & 1.30 & 2 & 0.5 \\
\hline October-December & $3 \cdot 6 \mathrm{r}$ & 2 & 0.15 \\
\hline
\end{tabular}

Only in May, June and August are significant year-to-year differences observed. These months are, of course, the times when the seasonal changes are most rapid, and hence irregularities in different years are most liable to occur. The reason why the year $194^{\circ}$ showed exceptional frequencies of gene arrangements both at Piñon Flats and at Andreas Canyon (see below) is a matter of speculation. It was a dry year but not exceptionally so. On the other hand, I $94 \mathrm{I}$ was a very wet year, and in mid-summer of $194 \mathrm{I}$ Drosophila pseudoobscura was more abundant at Piñon Flats than during any other year of collecting. The fact that ST chromosomes were relatively more common in I $94^{\mathrm{I}}$ than in $194^{\circ}$ and that $\mathrm{CH}$ chromosomes showed the opposite relationship is, then, not unexpected, since in every year ST are relatively more common in spring and $\mathrm{CH}$ in summer.

The absence of a sustained trend during the years of collecting at Piñon Flats is perhaps more apparent if one compares the collections made in 1945 and 1946 with those made earlier. The collection in I 945 was made on 30th April, and therefore it can be properly compared with the data either for April or for May of other years. Now, the frequency of ST in this collection is about 33 per cent. and of $\mathrm{CH}$ about 34 per cent. These frequencies are not significantly different from those observed at Piñon Flats in April 1940 or in May of 1939. The March 1946 collection contained about $5^{6}$ per cent. ST and 18 per cent. CH. This coincides as well as could be expected with the result obtained in March of I94I and in April of I939 and 1942. Finally, in June 1946 a high frequency of $\mathrm{CH}, 44$ per cent., and a low one of ST, 26 per cent. was found. This compares very closely with the data for June of 1940. 
Because no collecting has been done in Andreas Canyon since I 942 , and because the data to 1942 have been published previously (Dobzhansky, 1943), the situation in this locality can be dealt with only briefly here. Among the 3813 third chromosomes examined from Andreas Canyon, the frequency of ST is appreciably higher ( 57.6 per cent.) and that of $\mathrm{CH}$ lower ( 15.3 per cent.) than at Piñon Flats. Quite striking seasonal changes in the frequencies of ST and $\mathrm{CH}$ have been recorded. The frequencies of ST decline and of $\mathrm{CH}$ increase from March to June. Very few flies can be collected at Andreas from mid-June to August, but when the population begins to increase in numbers in September, ST chromosomes are found to have reached a high and $\mathrm{CH}$ a low frequency. No changes occur during autumn and winter. The cycle is, then, parallel to that observed at Piñon Flats. Significant variations in frequencies of the chromosomal types have been observed from year to year, but again, as at Piñon Flats, they were found almost entirely in 1940. During the spring of 1940 the frequencies of $\mathrm{CH}$ were consistently higher and of ST lower than during the corresponding months of I939, I94I and 1942. But no consistent trends can be discerned at Andreas for the whole period.

\section{DIRECTIONAL CHANGES IN THE KEEN CAMP POPULATION}

Among the 6634 third chromosomes of the Keen Camp population, 33.7 per cent. were ST, $23.8 \mathrm{AR}, 38 \cdot 0 \mathrm{CH}, 4.3 \mathrm{TL}$ and 0.2 Santa Cruz. Thus ST chromosomes are commonest at Andreas, less so at Piñon and least common at Keen. The reverse sequence is true of $\mathrm{CH}$ chromosomes; $\mathrm{AR}$ and $\mathrm{TL}$ chromosomes are about equally common in the three locations.

The data for Keen Camp are summarised in table 3. No seasonal changes comparable in magnitude and regularity to those known at Piñon Flats and Andreas Canyon are apparent at Keen. A statistical analysis can be made by examining the degree of homogeneity of the samples taken in different months of the same year. The results obtained are as follows (AR, TL and Santa Cruz chromosomes are combined for the purpose of the calculations) :-

\begin{tabular}{|c|c|c|c|}
\hline Year & $x^{2}$ & $\begin{array}{l}\text { Degrees of } \\
\text { freedom }\end{array}$ & $\mathbf{P}$ \\
\hline I 939 & $12 \cdot 03$ & Io & 0.3 \\
\hline I $94^{\circ}$ & $22 \cdot 37$ & 10 & 0.01 \\
\hline I 94 I & II OI & 6 & 0.09 \\
\hline 1946 & $8 \cdot 14$ & 2 & 0.02 \\
\hline
\end{tabular}

Significant changes from month to month were observed in 1940 , but apparently not in 1939 or 1941 . The samples taken in April and 
in June of 1946 are also significantly different. Reference to table 3 shows, however, that the changes in $194^{\circ}$ are not quite comparable to those familiar at Piñon Flats and Andreas Canyon ; at Keen there was a steady increase of ST from at least May till September I940, and a steady drop in the frequencies of $\mathrm{CH}$. The following winter apparently led to a decrease in ST and a rise in $\mathrm{CH}$, for in May of I94I the population had again a composition approximately like that of June and July of $194^{\circ}$. The year 1940, it will be recalled, produced unusual phenomena also at Piñon Flats and at Andreas Canyon. The change between April and June of 1946 was, if taken at face value, the same as expected in Piñon and Andreas populations at that season, namely an increase in $\mathrm{CH}$ and a drop in ST.

In contrast to the weakness and irregularity of the seasonal changes at Keen Camp is the consistent directional trend. Examination of table 3 shows that from 1939 to $194^{2}$ there was at Keen Camp

TABLE 3

Percentage frequencies of the gene arrangements in different samples at KEEN CAMP; $S T=$ Standard ; $A R=$ Arrowhead $; C H=$ Chiricahua ; $T L=$ Tree Line

\begin{tabular}{|c|c|c|c|c|c|c|c|c|c|c|c|}
\hline $\begin{array}{c}\text { Month } \\
\text { Yea }\end{array}$ & ST & $\mathbf{R}$ & $\mathrm{H}$ & $\mathrm{L}$ & $n$ & & ST & $\mathbf{R}$ & $\mathrm{CH}$ & $L$ & $n$ \\
\hline \multirow{2}{*}{$\begin{array}{l}\text { April 1939: } \\
\text { May 1939 } \\
\text { June 1939 } \\
\text { July 1939 } \\
\text { Aug. 1939 } \\
\text { Sept.-Oct. }\end{array}$} & \multirow{2}{*}{$\begin{array}{l}32 \cdot 5 \\
32 \cdot 6 \\
24 \cdot 8 \\
28 \cdot 6 \\
29 \cdot 5 \\
26 \cdot 0 \\
\end{array}$} & \multirow{2}{*}{$\begin{array}{l}30 \cdot 0 \\
28 \cdot 5 \\
30 \cdot 8 \\
29 \cdot 3 \\
30 \cdot 5 \\
35 \cdot 7\end{array}$} & \multirow{2}{*}{$\begin{array}{l}32 \cdot 5 \\
36 \cdot 2 \\
41 \cdot 2 \\
37 \cdot 3 \\
37 \cdot 6 \\
35 \cdot 1\end{array}$} & \multirow{2}{*}{$\begin{array}{l}5 \cdot 0 \\
2 \cdot 7 \\
3 \cdot 2 \\
4 \cdot 8 \\
2 \cdot 4 \\
3 \cdot 2 \\
\end{array}$} & \multirow{2}{*}{$\begin{array}{r}40 \\
298 \\
718 \\
566 \\
210 \\
154\end{array}$} & & $\begin{array}{l}29 \cdot 0 \\
3^{8 \cdot} \cdot 3 \\
35 \cdot 4 \\
3^{8} \cdot \mathbf{2}\end{array}$ & $\begin{array}{l}29 \cdot 4 \\
17 \cdot 6 \\
27 \cdot 2 \\
25 \cdot 0\end{array}$ & $\begin{array}{l}37 \cdot 9 \\
39 \cdot 3 \\
33.5 \\
32 \cdot 4\end{array}$ & $\begin{array}{l}3 \cdot 6 \\
4 \cdot 8 \\
3 \cdot 8 \\
4 \cdot 4\end{array}$ & $\begin{array}{r}248 \\
290 \\
158 \\
68 \\
\end{array}$ \\
\hline & & & & & & I &  & $24 \cdot I$ & $37 \cdot 1$ & -I & 764 \\
\hline Total & $27 \cdot 8$ & $30 \cdot 4$ & $3^{8 \cdot 3}$ & $3 \cdot 5$ & 1986 & & & & & & 10 \\
\hline & $\begin{array}{l}30 \\
26\end{array}$ & & & & & & & & & $\begin{array}{r}10 \cdot 0 \\
4 \cdot 0\end{array}$ & $\begin{array}{l}110 \\
100\end{array}$ \\
\hline & $\begin{array}{l}31 \cdot 3 \\
34 \cdot 5\end{array}$ & & & $\begin{array}{l}4 \\
3\end{array}$ & 8 & Total $194^{2}$ & 3 & 16.4 & $40 \cdot 3$ & 2 & 4 \\
\hline & & & & & & & & & & $\begin{array}{l}7.6 \\
8.8\end{array}$ & \\
\hline & 3 & 0 & $4^{I} \cdot 9$ & $4^{\circ} \cdot 0$ & 382 & & & $15^{\circ} \mathrm{O}$ & & $4 \cdot 5$ & 440 \\
\hline
\end{tabular}

a steady increase in the frequency of ST (from 28 per cent. in 1939 to 36 per cent. in 1942) and a drop in AR (from 30 per cent. in 1939 to 16 per cent. in $\left.194^{2}\right)$. This trend is highly significant statistically $\left(\chi^{2}=43 \cdot 82\right.$, probability for 6 degrees of freedom less than $\left.0 \cdot 001\right)$. No samples were taken in 1943 and 1944. The sample of late April I945 suggests that the trend continued during the intervening period, for ST chromosomes reached a frequency of $4^{\mathrm{I}}$ per cent.; AR chromosomes were as frequent as they were in $194^{\circ}$ and I94I, but $\mathrm{CH}$ showed the very low value of 29 per cent. The samples taken in 1946 demonstrated a further change in the same direction : $\mathrm{ST}$ rose to 50 per cent., AR dropped to $\mathrm{I} 5$ per cent. and $\mathrm{CH}$ to 28 per cent. If only the data for 1942 , 1945 and 1946 are taken into 
account, the alteration is still highly significant $\left(\chi^{2}=32 \cdot 2 \mathrm{I}\right.$, probability for 4 degrees of freedom less than $0 \cdot 001$ ). To eliminate the possible influence of whatever seasonal changes occur at Keen Camp, the degree of heterogeneity was measured among samples taken during the same months on different years. The results are as follows :-

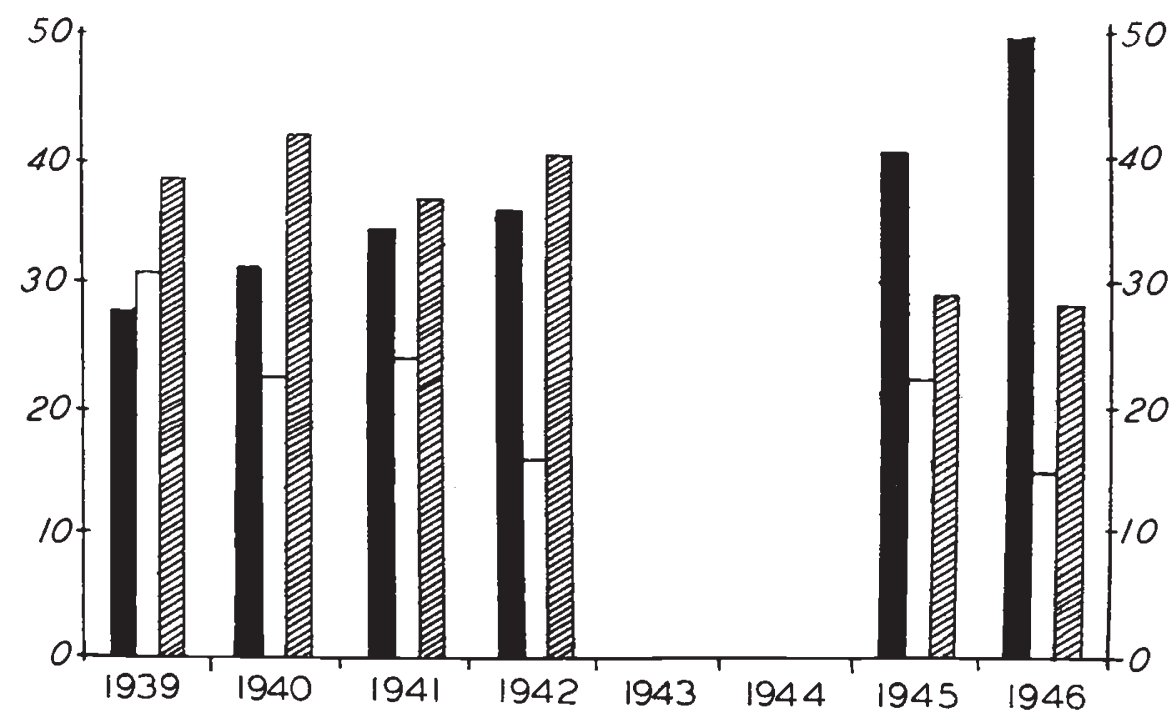

Fig. 2.-Relative frequencies of chromosomes with different gene arrangements on different years in the population of KEEN CAMP. Ordinates-frequencies in per cent. ; Black columns-ST chromosomes; white columns-AR chromosomes; and hatched columns - CH chromosomes.

The heterogeneity is significant except for the months of August and September-October. However, samples in August were taken

\begin{tabular}{|c|c|c|c|}
\hline Month & $x^{2}$ & $\begin{array}{l}\text { Degrees of } \\
\text { freedom }\end{array}$ & $\mathbf{P}$ \\
\hline $\begin{array}{l}\text { April } \quad: \\
\text { May } \\
\text { June } \\
\text { July } \\
\text { August } \\
\text { September-October }\end{array}$ & $\begin{array}{c}53 \cdot 9 \\
15 \cdot 8 \\
79 \cdot 6 \\
16 \cdot 3 \\
3 \cdot 05 \\
5^{\circ} \cdot 66\end{array}$ & $\begin{array}{l}8 \\
6 \\
8 \\
6 \\
2 \\
4\end{array}$ & $\begin{array}{c}<0.001 \\
0.02 \\
<0.001 \\
0.01 \\
0.22 \\
0.23 \\
0.23\end{array}$ \\
\hline
\end{tabular}

only on two successive years (1939 and 1940), and the SeptemberOctober samples are small. The year-to-year trend is unquestionably real.

\section{DISCUSSION}

The cyclic changes in the frequencies of gene arrangements which occur in the populations of Piñon Flats and Andreas Canyon are associated with the seasonal succession (Dobzhansky, 1943). Experi- 
ments on artificial populations bred in population cages have demonstrated that flies which carry different gene arrangements differ in adaptive value, inversion heterozygotes being favoured more than the homozygotes (Wright and Dobzhansky, 1946, and unpublished data). The observed cyclic seasonal changes are the result of natural selection, the wild populations reacting to seasonal alterations of their environment.

Although cyclic seasonal changes in frequency are very striking at Piñon Flats and Andreas Canyon, they are small or absent in the population of Keen Camp. This can mean either that the succession of seasons at Keen Camp is for some reason insufficient to provide the stimuli which induce the changes in the populations less than I 5 miles away, or that the chromosomes of the Keen Camp population differ in genic contents from those at Piñon Flats and Andreas Canyon. Experiments which may suggest a choice of these alternatives are under way, but for the time being the question must be left open. In any case, the Keen Camp population has a great genetic plasticity, since it is responding by a directional rather than a cyclic change. The former has continued for several successive years. It is highly probable that it also is the result of natural selection, although the specific factors producing it are still a matter for speculation.

Forest fires swept through parts of the Keen Camp locality and adjacent territory twice in $194 \mathrm{I}$ and again in 1942 . Because of partial destruction of the forest cover one would expect the environment of Keen Camp to have approached somewhat the conditions which exist normally at Piñon Flats, particularly in respect of the differences between the moist and dry periods of the growing season. Now, in I939 the Keen Camp population contained relatively more $\mathrm{CH}$ and fewer ST chromosomes than the yearly average for the Piñon Flats population. In 1945 and 1946 the reverse was true: the yearly average of the frequency of ST at Piñon Flats was lower than at Keen Camp. But it is known that the composition of the Piñon Flats population varies greatly from season to season, $\mathrm{CH}$ chromosomes increasing in frequency during spring and ST during the summer. The composition of the Keen Camp population in 1939 was similar to that of Piñon Flats during the month of June, while in 1946 it resembled the status of the Piñon Flats population from August to March. One might conclude, therefore, that greater aridity at Keen Camp caused by burning produced a change analogous to that which regularly takes place at Piñon Flats during summer. This conjecture is neither confirmed nor invalidated by the fact that the data for Keen Camp, if taken at face value, suggest that the directional changes in this locality began before the fires of ${ }^{1} 94^{\mathrm{I}}$ and $194^{2}$.

Another possibility is that the fly population which lived at Keen Camp in and before 1939 has for some reason been displaced by immigrants from the more arid Piñon Flats region. The forest fires 
may or may not have been instrumental in the displacement. On that assumption one might expect that the composition of the Keen Camp population would change from season to season in 1946 , although it did not do so in earlier years. Accordingly, samples were collected at Keen Camp in mid-April and in late June of 1946 (table 3). The frequencies of the gene arrangements in these samples proved to be significantly different, but the alterations which occurred between April and June of this year are not completely analogous to those which take place during the summer at Piñon Flats. The frequency of $\mathrm{CH}$ increased but that of ST fell only slightly; there was an apparent fall in the frequency of $\mathrm{TL}$ chromosomes which has no counterpart at Piñon Flats. Therefore, there is no reliable evidence that the Piñon Flats and Keen Camp populations have become alike in genetic constitution. The fact that the Piñon Flats population in late spring and in early summer of 1939 resembled that of Keen Camp might as easily lead to the supposition that the seasonal changes at Piñon Flats were due to immigration of flies from the flourishing Keen Camp populations. But there are several reasons why this supposition is unacceptable (Wright and Dobzhansky, I946); it is ruled out completely because the seasonal changes at Piñon Flats in 1946 conform to those of 1939 , although the composition of the Keen Camp populations have changed during the intervening years.

The seasonal changes in Drosophila pseudoobscura at Piñon Flats and at Andreas Canyon resemble those discovered in $D$. funebris by Dubinin and Tiniakov (1945, 1946a). An analogue of the nonseasonal change at Keen Camp may perhaps be found in the differences between the rural and urban populations of $D$. funebris observed by the same authors (1946b). Changes in the degree of urbanisation produced in a locality by war and other causes seem to be reflected in the composition of $D$. funebris populations.

Inversion heterozygotes of $D$. pseudoobscura are adaptively favoured as opposed to homozygotes. This circumstance makes the populations of this species very plastic and responsive to spatial as well as to temporal variations in the environment. But the genetic changes that take place in response to these variations do not lead to a depletion of the store of variability present.

\section{SUMMARY}

A directional change in the frequency of gene arrangements of the third chromosome of Drosophila pseudoobscura took place in the population at Keen Camp, Mount San Jacinto, California, between I 939 and 1946. The relative frequency of the Standard gene arrangement increased at the expense of the Arrowhead and Chiricahua arrangements. It is probable that this change was caused by natural selection, although it is a matter of speculation as to what environmental agents brought the change about. 
No directional changes occurred between 1939 and 1946 in the population of the Piñon Flats locality which lies less than 15 miles from Keen Camp. This population undergoes cyclic seasonal changes in the relative frequencies of the gene arrangements, and its composition fluctuates somewhat from year to year. However, an alteration took place in I $94^{\circ}$ which is not known to have occurred since.

\section{REFERENCES}

Dobzhansky, Тн. . . . . . . 1943. Genetics, 28, 162-г 86.

Dobzhansky, Th., and Epling, C. . 1944. Pub. Carnegie Inst., 554, I-183.

Dobzhansky, Th., and Sturtevant, 1938. Genetics, 23, 28-64.

A. $\mathrm{H}$.

Dobzhansky, Th., ANd Wright, S. I943. Ibid., 28, 304-340.

Dubinin, N P., and Tiniakov, G. G. I945. Amer. Natur., 79, 570-572.

$" \quad " \quad$ " $"$ r $946 a$. Ibid., 8o, 393-396.

, " $\quad " \quad$ I946b. F. Heredity, 37, 39-44.

Wright, S., And Dobzhansky, Th. . 1946. Genetics, 3I, I25-156.

Wright, S., Dobzhansky, Th., AND 1942. Ibid., 27, 363-394.

Hovanitz, W. 